\title{
Changes of Concentrations of Elements in Deciduous Teeth with Age
}

\author{
Agnieszka Fischer • Danuta Wiechula • \\ Celina Przybyla-Misztela
}

Received: 24 January 2013 / Accepted: 24 June 2013 / Published online: 9 July 2013

(C) The Author(s) 2013. This article is published with open access at Springerlink.com

\begin{abstract}
The aim of this study was to describe the issue of changes in the concentration of some elements ( $\mathrm{Mn}, \mathrm{Fe}, \mathrm{Mg}$, $\mathrm{Cu}, \mathrm{K}, \mathrm{Cr}, \mathrm{Pb}, \mathrm{Cd}$, and $\mathrm{Ca}$ ) in the mineral composition of deciduous teeth and to answer the question whether there was a tendency to change the metal concentration, depending on children's age. Physiological replacement of deciduous teeth is preceded with the remodeling process occurring in the mineral structure. The elemental composition of deciduous teeth tissue during their natural loss is the result of these transformations. The subject of the study was deciduous teeth taken from the children ( $n=45$, aged 5-14 years), residing in southern Poland, obtained as a result of noninvasive physiological replacement. The concentration of metals in samples was determined over the atomic absorption spectroscopy method. The results of the research showed a statistically significant decrease in the concentration of the analyzed elements in deciduous teeth of older children compared to younger children. The total concentration of all metals studied against the Ca content, expressed as the value of the constant cationic equilibrium, did not change in a statistically significant manner, depending on the age of the children $(p>0.05)$.
\end{abstract}

Keywords Deciduous teeth $\cdot$ Age $\cdot$ Elements

\section{Introduction}

Elements are a basic component of all tissues of living organisms. Some elements, numbered among physiologically essential components, play an important role in the functioning of tissues and organs. Our organism also absorbs

\footnotetext{
A. Fischer $(\bowtie) \cdot D$. Wiechuła $\cdot$ C. Przybyła-Misztela

Department of Toxicology, Medical University of Silesia,

4 Jagiellońska Street, 41-200 Sosnowiec, Poland

e-mail: afischer@sum.edu.pl
}

toxic elements. Their presence in the environment is a result of their natural existence or connected with anthropogenic and industrial activities. Toxic metals taken up by the body spread to different tissues and organs. Soft tissues are characterized by a dynamic exchange of elements. Hard tissues, which form our bones and teeth, accumulate most heavy metals absorbed by the body.

The structure of hard tissues is formed already during fetal life. The main component of hard tissues of the body, including teeth, is hydroxyapatite. Under physiological conditions, during the process of mineralization, various elements can be included in the hydroxyapatite structure. Their significance can be both physiological (e.g., $\mathrm{Ca}, \mathrm{Mg}, \mathrm{Na}, \mathrm{K}$ ) and toxic (e.g., $\mathrm{Pb}, \mathrm{Cd}$ ). The hydroxyapatite, which forms teeth tissues, has a particularly stable elemental structure; however, during lifetime, there are some modifications to its elemental composition [1]. The elemental composition of the hydroxyapatite of teeth changes is a long-term process, which means that the metals that are included in its structure are released only to a small extent. Metals absorbed into the body and deposited in the teeth tissue remain there throughout lifetime. Thus, in conditions of occupational or environmental exposure, the concentration of toxic elements in teeth increases with age [2]. This feature determines the usefulness of teeth when assessing a long-term exposure [3].

Deciduous teeth are a biological material that in relation to the process of physiological replacement of teeth with permanent dentition may be obtained over a noninvasive method. What is more, it may be used to assess the concentration of elements in the body. Another typical fact is that the loss of specific types of deciduous teeth (e.g., incisors, canines) takes place in certain periods of a child's age. Several studies have revealed that the aging process may affect enamel physic properties related to the mineral composition [4-7]. In the case of deciduous teeth, resorption processes, which occur before the teeth loss, may also influence the mineral composition of hard tissues. 
The aim of our research was to analyze the concentration of chosen physiological ( $\mathrm{Ca}, \mathrm{Mn}, \mathrm{Fe}, \mathrm{Mg}, \mathrm{Cu}, \mathrm{K}$, and $\mathrm{Cr}$ ) and toxic $(\mathrm{Pb}$ and $\mathrm{Cd})$ elements in hard tissues of deciduous teeth of children prior to their physiological replacement. Population of children lived in the southern regions of Poland. This area is highly industrialized, and its inhabitants are to a great extent exposed to heavy metals. This paper examines whether and to what extent children's age, at which there was a physiological tooth loss, influences the concentration of chosen elements and the stability of elemental composition. Moreover, mutual quantitative relations between the studied elements in the structure of hard tissues in deciduous teeth were analyzed. Studies on the elemental composition of tissues usually focused on determining the levels of the individual components. They are also used correlation and regression methods [2, 8, 9]. In this study in addition to the above methods, to determine the mutual quantitative relations of elements in the structure of hard tissues of deciduous teeth, we used a cationic equilibrium hypothesis [10]. The cationic equilibrium hypothesis has been used in research concerning the elemental composition of both plant and animal tissues [10-12]. This hypothesis is based on the fact that the elemental composition of the studied tissues, in relation to the content of the main, relatively stable element that builds the structure of a given tissue, is a constant value. Further to the above assumption, the analysis of changes in the content of the analyzed elements ( $\mathrm{Mn}, \mathrm{Fe}, \mathrm{Mg}, \mathrm{Cu}, \mathrm{K}, \mathrm{Cr}, \mathrm{Pb}$, and $\mathrm{Cd}$ ) in deciduous teeth was conducted with respect to the content of calcium as a reference element. Its content in the mineral structure of hard tissues of teeth is the highest.

\section{Materials and Methods}

\section{Subject}

The subject of the study was deciduous teeth of healthy children living in southern Poland, in a town of the Silesian Province (Katowice, Ruda Śląska, Świętochłowice), from birth. To maintain an invariable environmental exposure to metals in terms of an area, the study did not include the teeth of children born outside the Silesian Province or those who changed their place of residence in the course of their lifetime. Children treated for chronic diseases were also excluded from the research. The studies were conducted with the approval of the relevant bioethical committee (SUM no. NN6501-109/06). Deciduous teeth were collected from children during permanent physiological replacement of deciduous teeth. The study included 45 deciduous teeth from girls and boys aged 5-14 (mean age $8 \pm 2.28$ years). Teeth with dental fillings and those with decayed teeth crowning were not subject to laboratory tests $(<300 \mathrm{mg})$.
Preparation of Samples

After a thorough cleaning process, washing and rinsing with distilled water, deciduous teeth were dried to constant mass $\left(85^{\circ} \mathrm{C} / 24 \mathrm{~h}\right)$. Then, they were crushed using a porcelain mortar. They were dried once again $\left(85^{\circ} \mathrm{C} / 3 \mathrm{~h}\right)$. Each tooth provided for $300 \mathrm{mg}$ of averaged sample that was given to further analysis [13].

All the instruments used during the teeth preparation phase were washed with $10 \%$ nitric acid (Merck) and then rinsed ten times with redistilled water and dried in a laboratory incubator $\left(70^{\circ} \mathrm{C}\right)$. All the chemical reagents used during the analysis and preparation had been awarded quality certificates.

The teeth of known dried mass were mineralized using $3 \mathrm{~cm}^{3}$ spectrally pure nitric acid (Suprapur; Merck) in the Teflon vessel for $24 \mathrm{~h}$ at a temperature of $23 \pm 2{ }^{\circ} \mathrm{C}$ and then heated up to a temperature of ca. $120^{\circ} \mathrm{C}$ to obtain a clear solution which was diluted with redistilled water to $10 \mathrm{~cm}^{3}$ [14]. Lanthanum chloride was added for calcium determination with final diluted solution of $1 \%$ before the sample analysis. The lanthanum chloride was prepared using $\mathrm{La}_{2} \mathrm{O}_{3}$ (Merck) and $36 \% \mathrm{HCl}$ (Merck), and redistilled water was added prior to calcium determination [15].

The determination of the metals in the teeth was carried out over the atomic absorption spectroscopy (AAS) method (AAS-3, Carl Zeiss Jena).

The verification of determination accuracy was established by means of the standard addition method using the model of mass concentration of given metals. For calibration, the working solutions were prepared by precisely measured dilution of stock solutions with redistilled water. Blank samples were used after every ten samples. The procedure was validated by NIST 1486 (bone meal) (Table 1).

Table 1 Analysis of NIST 1486 (bone meal) by AAS (microgram per gram) and $\mathrm{Ca}$ and $\mathrm{Mg}$ (percent)

\begin{tabular}{lllcc}
\hline Metal & Certified/noncertified & $\begin{array}{l}\text { Measured } \\
(n=6)\end{array}$ & Recover \% & Accuracy \% \\
\hline $\mathrm{Cd}$ & $0.003^{\mathrm{a}}$ & 0.0029 & 93.3 & -6.7 \\
$\mathrm{Cu}$ & $0.8^{\mathrm{a}}$ & 0.87 & 108.8 & 8.8 \\
$\mathrm{Fe}$ & $99^{\mathrm{b}}$ & 93 & 93.9 & -6.1 \\
$\mathrm{Mn}$ & $1^{\mathrm{a}}$ & 0.98 & 98.0 & -2.0 \\
$\mathrm{~Pb}$ & $1.335^{\mathrm{b}}$ & 1.228 & 92.0 & -8.0 \\
$\mathrm{Zn}$ & $147^{\mathrm{b}}$ & 140 & 95.2 & -4.8 \\
$\mathrm{Mg}$ & $0.466^{\mathrm{b}}$ & 0.491 & 105.4 & 5.4 \\
$\mathrm{Ca}$ & $26.58^{\mathrm{b}}$ & 24.67 & 92.8 & -7.2 \\
$\mathrm{~K}$ & $412^{\mathrm{b}}$ & 384 & 93.2 & -6.8 \\
\hline${ }^{\mathrm{a}}$ Noncertified & & & \\
${ }^{\mathrm{b}} \mathrm{Certified}$ & & &
\end{tabular}


Statistical Analysis

Statistical results were calculated by STATISTICA 10 for Windows. Due to the fact that the distribution of results in various groups was not normal (Shapiro-Wilk test, $p<0.05$ ), nonparametric tests were used in the statistical analysis of the results. To estimate the statistical significance, ANOVA rang Kruskal-Wallis test was used. The study on the interaction between age and metal concentrations in deciduous teeth was based on Spearman's rank test. It was considered as a statistically significant probability, $p \leq 0.05$.

The value of the constant cationic equilibrium was set to determine the mutual quantitative relations between the studied elements in hard tissues of deciduous teeth. The constant cationic equilibrium is based on a hypothetical assumption that the elemental composition of the tissues is constant [12]. This value was calculated based on the total average concentrations of all metals in relation to the concentration of calcium as a reference element. According to the assumption of the cationic equilibrium hypothesis, the reference element should play the main physiological role in the studied tissue, e.g., calcium in the osseous tissue $[16,17]$. Another reason is that an element which decides the mineral composition of hydroxyapatite exhibits current capability to exchange ions $[1,16,18]$.

$\mathrm{CEC}=\sum C_{i} \sqrt{\frac{\left[E_{i}\right]}{\sum[E]}}=\mathrm{const}$

where:

CEC cationic equilibrium constant

$\mathrm{E}_{i} \quad$ cation $i$ concentration

$\mathrm{E} \quad$ sum of the concentrations of cations

$\mathrm{C}_{i} \quad$ quotient of $\mathrm{E}_{i}$ cation concentration to the concentration of a reference element, an element of primary physiological significance, e.g., Ca for osseous tissue [11, 12].

\section{Results}

Table 2 shows the contents of the analyzed elements in deciduous teeth of the studied group of children. The conducted statistical analysis included defining the range of changes in the content of the studied metals, arithmetic mean, median, standard deviation value, and coefficient of variation.

Among the studied metals, physiological elements $(\mathrm{Ca}, \mathrm{K}$, $\mathrm{Mg}$ ) constituted the greatest quantities in deciduous teeth. The content of toxic $\mathrm{Cd}$ and microelements $(\mathrm{Mn}, \mathrm{Cu}$, and $\mathrm{Cr}$ ) in deciduous teeth was the lowest (Table 2). The character and direction of changes in the contents of the studied elements in the age function was assessed with the use of the correlation analysis (Table 2). The graphic representation of the analysis conducted is an exemplary graph of $\mathrm{Pb}$ content changes in hard tissues of deciduous teeth as a function of age (Fig. 1). Values of the constant cationic equilibrium, which ranged 9.91-9.94, were set in order to determine mutual quantitative proportions between the studied metals in hard tissues of deciduous teeth. Figure 2 shows the changes in the value of the constant cationic equilibrium in the analyzed age groups of the children studied: 5-6 years $(n=9), 7-9$ years $(n=15)$, and $10-14$ years $(n=16)$.

\section{Discussion}

Several research studies have shown that physiological elements, including $\mathrm{Ca}$ that is the main component of hydroxyapatite, have the highest concentration in hard tissues of teeth (Table 2). The level of Cd was shown to be the lowest (0.18$1.70 \mu \mathrm{g} / \mathrm{g}$ ) (Table 2), and its concentration in hard tissues of teeth was mostly due to environmental pollution. The study results are in accordance with the data from the literature [2, 19]. The analysis of changes in the concentrations of the analyzed elements in deciduous teeth, defined by the coefficient of variation, showed the least variability in the concentration of $\mathrm{Cr}$ and then $\mathrm{K}, \mathrm{Cu}$, and $\mathrm{Mg}$. The greatest variability
Table 2 Statistical characteristic of metal concentration in deciduous teeth, $n=45$ (microgram per gram) and $\mathrm{Ca}$ and $\mathrm{Mg}$ (percent)

\begin{tabular}{llllll}
\hline & Arithmetic mean & Range & SD & Median & Coefficient of variation \\
\hline $\mathrm{Mn}$ & 4.39 & $0.73-12.9$ & 2.97 & 3.72 & 67.8 \\
$\mathrm{Fe}$ & 51.0 & $14.0-108$ & 23.9 & 49.9 & 47.1 \\
$\mathrm{~Pb}$ & 13.4 & $4.00-29.2$ & 6.34 & 12.6 & 47.4 \\
$\mathrm{Cd}$ & 0.70 & $0.18-1.70$ & 0.39 & 0.61 & 56.3 \\
$\mathrm{Cu}$ & 4.62 & $2.33-8.26$ & 1.39 & 4.74 & 30.1 \\
$\mathrm{Cr}$ & 8.97 & $5.34-12.9$ & 1.94 & 8.67 & 21.7 \\
$\mathrm{~K}$ & 240 & $121-403$ & 67.5 & 236 & 28.1 \\
$\mathrm{Ca}$ & 20.0 & $6.60-52.1$ & 11.9 & 17.7 & 59.5 \\
$\mathrm{Mg}$ & 2,367 & $698-4,416$ & 713 & 2,265 & 30.2 \\
\hline
\end{tabular}


Fig. 1 The relationship between concentration of lead in deciduous teeth and age of children

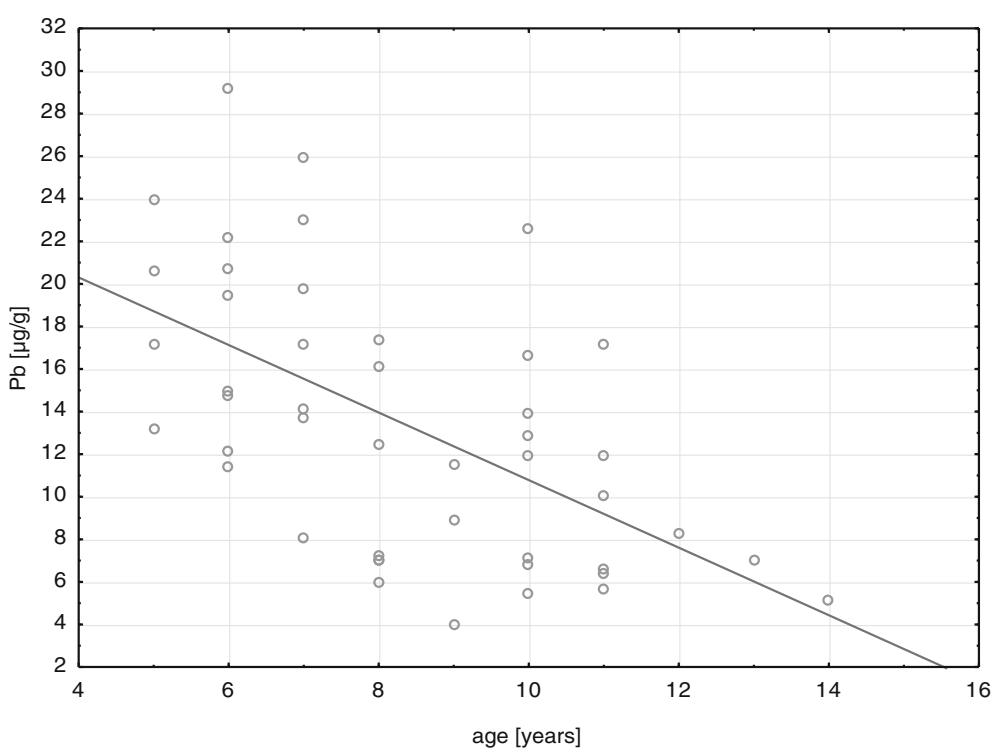

was noted in the concentration of $\mathrm{Mn}$ and $\mathrm{Ca}$. The concentration of heavy metals, $\mathrm{Pb}$ and $\mathrm{Cd}$, characterized by relatively high values of the coefficient of variation, indicates a varied environmental exposure of the population of the subjects (children) (Table 2).

Correlation analyses were conducted in order to evaluate the relation between the concentration of metals and children's age (Table 3). The study results showed that levels of all analyzed elements in deciduous teeth decreased with age. The greatest decrease occurred in the concentration of trace elements - $\mathrm{Cr}, \mathrm{Pb}, \mathrm{Cd}$, and $\mathrm{Cu}$. Research studies by other authors have reported accumulation of metals, mainly heavy

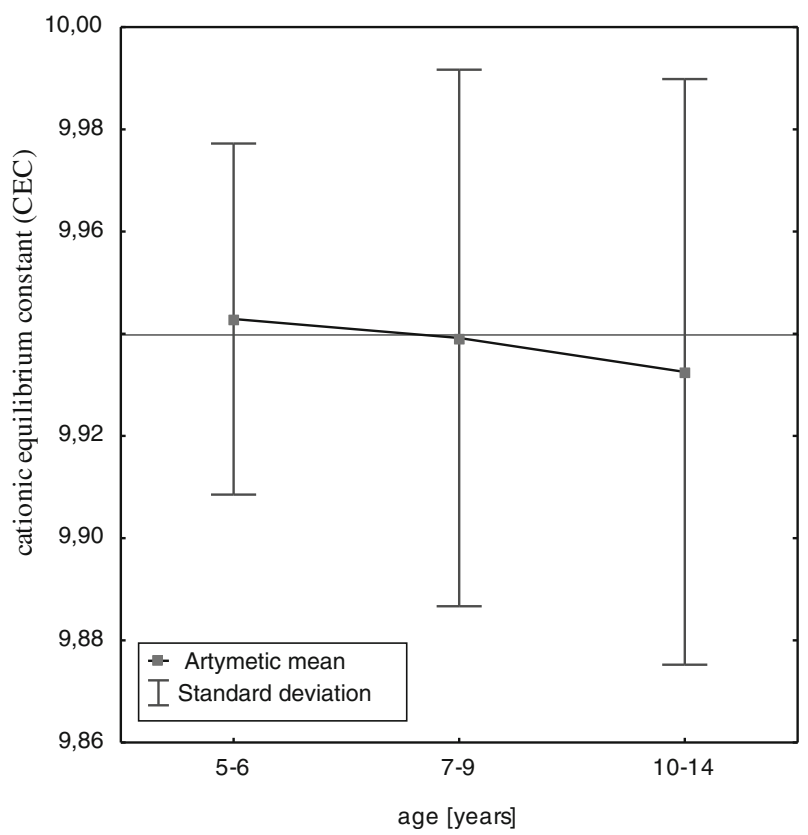

Fig. 2 Dependence between the cationic equilibrium constant and the age of the primary teeth metals, in hard tissues as a result of long-lasting exposure [2, 20]. This phenomenon was not confirmed in this study (Table 3, Fig. 1). The observed smaller concentration of trace elements in deciduous teeth of older children compared with younger ones may indicate a progressive demineralization in the preparation process of teeth tissues for natural replacement. The concentration of $\mathrm{Ca}$, the main component of hard tissue of teeth, in the studied deciduous teeth decreased with the age of the children (Table 3). This confirms the earlier observed mineral changes in the structure of hard tissues that occur with age [4]. In this study, only the concentration of Fe and $\mathrm{Mn}$ in teeth of the respondents did not decrease significantly with age $(p \leq 0.05)$. The obtained results were a motivation to analyze the overall changes in the concentration of the analyzed elements in deciduous teeth. For individual tissues, it is possible to work out the parameter of the socalled constants of cationic equilibrium [21]. The calculated arithmetic mean value of the constant cationic equilibrium

Table 3 Spearman's correlation coefficient $(r)$ between metal concentration in deciduous teeth and age of children

\begin{tabular}{ll}
\hline & $r$ value \\
\hline $\mathrm{Fe}$ & -0.28 \\
$\mathrm{Mn}$ & -0.21 \\
$\mathrm{Ca}$ & $-0.37^{*}$ \\
$\mathrm{Mg}$ & $-0.35^{*}$ \\
$\mathrm{Cd}$ & $-0.50^{*}$ \\
$\mathrm{Cu}$ & $-0.47^{*}$ \\
$\mathrm{~Pb}$ & $-0.60^{*}$ \\
$\mathrm{~K}$ & $-0.38^{*}$ \\
$\mathrm{Cr}$ & $-0.46^{*}$ \\
$\mathrm{Cationic}$ equilibrium & -0.20 \\
\multicolumn{2}{c}{ constant (CEC) } \\
\hline
\end{tabular}

${ }^{*} p \leq 0.05$, statistically significant correlations 
constant, which shows the changes in the contents of particular elements on the background of the total content of these elements including the content of calcium as a reference element, amounted 9.94 and was consistent with the results of other studies $[22,23]$. With the age of the studied children, as opposed to significant changes in the concentration of analyzed elements in teeth tissues, the value of the constant cationic equilibrium did not change in a statistically significant manner $(p \leq 0.05)$ (Table 3). The value of the coefficient of correlation $r=-0.20(p>0.05)$ showed no significant relation between these variables (Table 3 ) and indicates the quantitative balance of the elemental composition of hard tissues of deciduous teeth. The value of the cationic equilibrium constant reflects the homeostasis of body tissues, in this case the hard tissue. Homeostasis is the result of many biochemical processes taking place at the same time, including absorption, transformation, and removal of elements and interactions that occur between them. By hypothesis of the cationic equilibrium constant, concentration of the individual cations with respect to the total content of these cations in the biological system is a constant value, which means that the value of the cationic equilibrium constant affects the cationic concentration of all metals tested in a given tissue and the concentration of the element characteristic of the physiology of the tissue [12]. Such element in the teeth is calcium, which is present in the mineralized tissue in high concentration and has an important physiological role. Low variation of the cationic equilibrium constant found in this study, compared to the diversity of metal concentration in teeth of children of all ages, supports the striving of the elemental composition of teeth after equilibrium, which in practice results in parallel changes in the concentration of toxic elements and elements of physiological importance in tissue.

Figure 2 shows the calculated values of the cationic equilibrium constant in the teeth of children, divided into the following age groups (5-6, 7-9, and 10-14 years). In the teeth of the youngest children (5-6 years), the calculated value of the cationic equilibrium constant was the highest and exceeded the average value of the cationic equilibrium constant calculated for the teeth of all children studied (9.94). In the teeth of the youngest children, the value of the standard deviation of cationic equilibrium constant was the lowest. With the increasing age of the children studied, the arithmetic mean value of the cationic equilibrium constant decreased, and the oldest age group ( $n=10-14$ years) had the lowest value $=9.93$. Decrease in the value of the cationic equilibrium constant in the age groups of children studied was not statistically significant $(p \leq 0.05)$. On the background of the statistically significant decrease in the concentration of particular elements $(\mathrm{Cr}, \mathrm{K}, \mathrm{Pb}, \mathrm{Cu}, \mathrm{Cd}, \mathrm{Mg}, \mathrm{Ca})$ in the age function, the change in the mineral structure of the teeth in the general range of the analyzed metals, illustrated by the calculated value of the cationic equilibrium constant, showed no statistically significant differences (Fig. 2). However, the decrease in the value of the cationic equilibrium constant and the increasing value of the standard deviation in the group of older children in the study (7-14 years old) can illustrate the changes in the mineral structure of teeth with age. A statistically insignificant decrease in the value of the constant cationic equilibrium in the teeth of the oldest children (1314 years) (Fig. 2) may indicate a more intense process of changing the mineral structure of teeth as a result of aging.

\section{Conclusion}

1. The concentration of all metals in the tissues of deciduous teeth decreased with age. The decrease in the concentrations in most studied metals $(\mathrm{Ca}, \mathrm{Mg}, \mathrm{Cd}, \mathrm{Cu}, \mathrm{Pb}$, $\mathrm{K}, \mathrm{Cr}$ ) in deciduous teeth was statistically significant $(p \leq 0.05)$.

2. The calculated value of the constant cationic equilibrium, which shows the changes in all studied elements, did not change in a statistically significant way with age $(p>0.05)$.

3. The analysis of the total concentration of the studied metals, expressed as the constant cationic equilibrium value, shows that there is a quantitative equilibrium in the elemental composition of hard tissues of teeth.

Open Access This article is distributed under the terms of the Creative Commons Attribution License which permits any use, distribution, and reproduction in any medium, provided the original author(s) and the source are credited.

\section{References}

1. Wakamura M, Kandori K, Ishikawa T (1998) Surface composition of calcium hydroxyapatite modified with metal ions. Colloids Surface A: Physicochem Eng Aspects 142:107-116

2. Kumagai A, Fujata Y, Endo S, Itai K (2012) Concentrations of trace element in human dentin by sex and age. Forensic Sci Int 219:29-32

3. Tvinnereim HM, Eide R, Riise T (2000) Heavy metals in human primary teeth: some factors influencing the metal concentration. Sci Total Environ 255:21-27

4. He B, Huang S, Zhang C, Jing J, Hao Y, Xiao L, Zhou X (2011) Mineral densities and elemental content in different layers of healthy human enamel with varying teeth age. Arch Oral Biol 56:997-1004

5. Park S, Quinn JB, Romberg E, Arola D (2008) Mechanical properties of human enamel as function of age and location in the tooth. J Mater Sci Mater Med 19:2317-24

6. Palti DG, Machado MA, Silva SM, Abdo RC, Lima JE (2008) Evaluation of superficial microhardness in dental enamel with different eruptive ages. Braz Oral Res 281:41-5

7. Zaichick V (2009) Neutron activation analysis of $\mathrm{Ca}, \mathrm{Cl}, \mathrm{K}, \mathrm{Mg}$, $\mathrm{Mn}, \mathrm{Na}, \mathrm{P}$ and $\mathrm{Sr}$ contents in the crowns of human permanent teeth. J Radioanal Nucl Chem 281:41-5

8. Costa de Almeida GR, de Sousa GC, de Angelo Souza Leite G, Antonio RC, Barbosa F Jr, Tanus-Santos JE, Gerlach RF (2011) Lead 
contents in the surface enamel of primary and permanent teeth, whole blood, serum, and saliva of 6- to 8-year-old children. Sci Total Environ 409(10):1799-1805

9. Gomes VE, de Sousa R, Mda L, Barbosa F Jr, Krug FJ, Pereira Saraiva Mda C, Cury JA, Gerlach RF (2004) In vivo studies on lead content of deciduous teeth superficial enamel of preschool children. Sci Total Environ 320:25-35

10. Kwapuliński J, Brodziak-Dopierała B, Okrajni J, Koczy B, Toborek $\mathrm{J}$ (2005) Cationic equilibrium in osseous tissue on the example of the femur capitulum (in Polish). Ann Acad Med Siles 59:30-34

11. Kosiba P, Kolon K (2002) Disturbances of ionic equilibrium in mosses of contaminated areas. Acta Soc Bot Pol 71(4):323-328

12. Samecka-Cymerman A, Kempers AJ, Kolon K (2000) Concentrations of heavy metals in aquatic bryophytes used for biomonitoring in rhyolite and trachybasalt areas: a case study with Platyhypnidium rusciforme from the Sudety Mountains. Ann Bot Fennici 37:95-104

13. Fischer A, Kwapuliński J, Wiechuła D, Fischer T (2008) The occurrence of copper in deciduous teeth of girl and boys living in upper Silesian industry region (southern Poland). Sci Total Environ 389:315-319

14. Wiechuła D, Fischer A, Kwapuliński J, Loska K, Fischer T, Kurpas P (2006) Multivariate statistical analysis of metal concentrations in teeth of residents of Silesian region, southern Poland. Arch Environ Contam Toxicol 51:314-320

15. Malara P, Kwapuliński J, Malara B (2006) Do the levels of selected metals differ significantly between the roots of carious and noncarious teeth? Sci Total Environ 369:59-68
16. Jurkiewicz A, Wiechuła D, Nowak R, Gaździk T, Loska K (2004) Metal content in femoral head spongious bone of people living in regions of different degrees of environmental pollution in southern and middle Poland. Ecotoxicol Environ Saf 59:95-101

17. Tzaphlidou M, Zaichick V (2003) Calcium, phosphorus, calciumphosphorus ratio in rib bone of healthy humans. Biol Trace Elem Res 93:63-74

18. Sugiyama S, Moriga T, Goda M, Hayashi H, Moffat JB (1996) Effect of fine structure changes of strontium hydroxyapatites on ion exchange properties with cations. J Chem Soc Faraday Trans 21:4305-4311

19. Fischer A, Wiechuła D, Postek-Stefańska L, Kwapuliński J (2009) Concentrations of metals in maxilla and mandible deciduous and permanent human teeth. Biol Trace Elem Res 1(132):19-26

20. Alomary A, Al-Momani IF, Massadeh AM (2006) Lead and cadmium in human teeth from Jordan by atomic absorption spectrometry: some factors influencing their concentrations. Sci Total Environ 369:69-75

21. Kwapuliński J, Brodziak B, Kowol J (2004) Cationic equilibrium of selected elements in Digitalis purpureae (L.) (in Polish). Herba Polonica 50(2):65-70

22. Kwapulinski J, Fischer A, Wiechuła D (2004) The constant of cationic equilibrium in selected types of teeth under conditions of changing environmental exposure to metals (in Polish). Czas Stomatol 4(57):237-245

23. Malara P, Kwapuliński J, Malara B (2003) Zastosowanie stałej równowagi kationowej obliczanej dla zębów w ocenie narażenia środowiskowego populacji. Bromat Chem Toksykol 4(36):373-381 